\title{
TESTAREA PRIMERILOR SPECIFICI PENTRU DETECT,IA 'Candidatus Phytoplasma solani'
}

\author{
Bahșiev Aighiuni, Mitin V., Zamorzaeva Irina \\ Institutul de Genetică, Fiziologie și Protecție a Plantelor, Chișinău, Republica Moldova \\ e-mail: bahsiev.aighiuni@gmail.com
}

Fitoplasma este un microorganism fără perete celular care infectează plantele, fiind propagat prin floem la un spectru larg de culturi agricole de importanță economică majoră ca de exemplu: grâu, porumb, cartof ș.a. În special infectează tomatele, simptomele tipice ale infecției se manifestă prin piticism, îngălbenirea frunzelor, scurtarea internodurilor și sterilitatea înflorescenței, ce duce în final la scăderea semnificativă a calității producției și a productivității. Detecția morfologică este greu de realizat, din motiv că fitoplasmoza prezintă simptome specifice și altor infecții virale iar simtomele distinctive se observă la etapele tardive de creștere a tomatelor când are loc infecția sistemică în plante. La fel diagnosticul fitoplasmei este mai dificil din cauza imposibilității cultivării in vitro. Pe când metodele moleculare permit identificarea veridică și specifică a fitoplasmei. De obicei detecția moleculară a fitoplasmei se realizează prin metoda nested-PCR care constă în amplificarea în două runde a secvenței specifice. Însă această metodă posedă unele dezavantaje fiindcă consumă mult timp și reactive. Scopul cercetării a constat în optimizarea condiţiilor de identificare a 'Candidatus Phytoplasma solani' într-o singură rundă, astfel am realizat testarea primerilor specifici pentru detecția sigură a fitopatogenului la plante.

Materialul a fost colectat la etapa de coacere în masă a fructelor în luna august a anului 2018, când titrul fitoplasmei atinge un nivel înalt în plante. Izolarea ADN-ul s-a realizat prin metoda DNAzol din 10 plante a soiului Elvira. Soiul Elvira fiind considerat ca soi sensibil la infecția fitoplasmică. În studiu au fost analizați șase primeri ps (3 Forward și 3 Revers în diferite combinați), specifici pentru 'Ca. P. solani'. Primeri au fost creați cu ajutorul programei Primer 3, pe baza secvenței genei chaperonin. Reacția de amplificare a decurs conform următorului program : I - $94^{\circ} \mathrm{C} 5^{\prime}$; II - $94^{\circ} \mathrm{C} 30^{\prime \prime}$, $58^{\circ} \mathrm{C} 30^{\prime \prime}, 72^{\circ} \mathrm{C} 30^{\prime \prime} \times 30$; III $-72^{\circ} \mathrm{C} 10^{\prime}$; IV $-4^{\circ} \mathrm{C} \infty$. Rezultatele amplificării au fost înregistrate prin electroforeza ampliconilor coloraţi cu bromură de etidiu (gel de agaroză de $2 \%$, soluţie-tampon 1xTBE) şi vizualizaţi în UV. Veridicitatea metodei de detecţie a fitoplasmei a fost determinată pe baza datelor obținute cu ajutorul metodei nested-PCR.

Iniţial s-a realizat testarea primerilor ps3-ps4. Rezulatetele detecției moleculare a ' $C a$. P. solani' cu primerii ps3-ps4 au demonstrat prezența a 8 semnale de amplificare din 10 probe analizate. În urma comparației datele obținute prin metoda PCR au fost identice cu rezultatele primite prin metoda nested-PCR. Utilizând primerii ps1-ps4 la fel s-au demonstrat rezultate asemanătoare iar semnalele de amplificare fiind mai accentuate.

Diagnosticul molecular al fitoplasmei cu perechea de primerii ps3-ps6 nu a prezentat o sensibilitate atât de înaltă fiind prezente 7 semnale de amplificație din 10 probe, mai mult ca atât s-a atestat sinteza unor fragmente de ADN cu lungimi nespecifice. Date similare au fost obținute și prin utilizarea primerilor ps1-ps5. În acest caz au fost determinate 6 benzi din cele 8 obținute în urma realizării nested-PCR.

Analizând rezultatele primite putem menționa că perechea de primeri ps1-ps4 este cea mai potrivită pentru identificarea sigură și precisă a fitoplasmei. La fel primerii ps3-ps4 pot fi utilizați în diagnosticul molecular al ' $\mathrm{Ca}$. P. solani' dar benzile electroforetice (semnele de infecție) nu au fost așa de accentuate în acest caz. Perechea ps3-ps6 nu a demonstrat rezultate veridice, dar pe viitor pot fi analizate și alte condiții de realizare a PCR. Perechea de primeri ps1-ps5 a prezentat rezultate falsnegative și nu necesită de a fi inclusă în cercetările ulterioare pentru diagnosticul molecular al fitoplasmei prin metoda PCR.

În concluzie putem recomanda perechile de primeri ps1-ps4 și ps3-ps4 pentru detecția moleculară sigură și precisă a 'Ca. P. solani'. Primerii dați demonstrează o sensibilitate înaltă permițând obținerea rezultatelor veridice, cu minimizarea timpului și a reactivelor utilizate. 